\title{
PREVALENCE OF HAEMONCHOSIS OF GOATS AT RAJSHAHI DISTRICT IN BANGLADESH
}

\author{
L. Nahar ${ }^{1 *}$, M. J. U. Sarder ${ }^{1}$, M. M. H. Mondal ${ }^{2}$, M. O. Faruque ${ }^{3}$ and M. Rahman ${ }^{1}$ \\ ${ }^{1}$ Department of Animal Husbandry and Veterinary Science, Faculty of Agriculture, University of Rajshahi, \\ Rajshahi-6205, Bangladesh \\ ${ }^{2}$ Department of Parasitology, Faculty of Veterinary Science, Bangladesh Agricultural University, \\ Mymenshingh-2202, Bangladesh \\ ${ }^{3}$ Department of Animal Breeding and Genetics, Faculty of Animal Husbandry, Bangladesh Agricultural \\ University, Mymenshingh-2202, Bangladesh
}

\begin{abstract}
A study was conducted in the Laboratory of Animal Husbandry and Veterinary Science, University of Rajshahi, Rajshahi, Bangladesh, during March, 2011 to February, 2012. The aim of this study was to determine the effects of temperature, humidity and rainfall in different months on the prevalence of haemonchosis of goats in Rajshahi, Bangladesh. A total of 720 samples were examined, of these (416) $57.8 \%$ goats were found positive for Haemonchus spp. infection. The highest prevalence was observed in the month of July $(82.1 \%)$ followed by August $(79.7 \%)$ and lowest in the January $(28.3 \%)$ followed by February $(38.7 \%)$. It was also observed that temperature $\left(29.8^{\circ} \dot{\mathrm{C}}\right)$, relative humidity $(86 \%)$ and rainfall $(146.0$ $\mathrm{mm}$ ) in the month of July was favourable for the egg laying, hatching and survival of infective larvae on the pasture. On the other hand, all the factors like temperature, humidity and rainfall was recorded lowest as $17.5^{\circ} \dot{\mathrm{C}}, 79 \%, 5.5 \mathrm{~mm}$ respectively which was unfavourable for the reproduction and survival of infective larvae in the month of the January. The current study revealed that haemonchosis is an important and common parasitic disease and requires special attention for its control. The prevalence among different months when compared statistically (Chi-square test and DMRT) revealed significant $(\mathrm{P}=0.001)$ differences. So, it is concluded that, month of the year, temperature, humidity and rainfall has significance effect on the prevalence of haemonchosis in goats. Considering those factors control should be carried out in and around Bangladesh to improve our goat production.
\end{abstract}

Key word: Haemonchosis, Goats, Month, Bangladesh

\section{INTRODUCTION}

Livestock sector comprises an integral component of the country's crucial and largely subsistence economy. The population size of livestock in Bangladesh are estimated to be 23.43 million cattle, 1.45 million buffalo, 25.61 million goats, and 3.15 million sheep up to February, 2014 (BER, Bangla, 2014). The total livestock population is about 536.60 (lacs) contributing 37.38 (lac ton) milk and 30.21 (lac ton) meat (BER, Bangla, 2014). Goat is a very important ruminant species in Bangladesh. They are highly prolific, have short generation interval and the products are easily marketable. Goats make a significant contribution to the maintenance of household stability, improved household nutrition, alleviation of hunger, better livelihoods, more effective utilization of unpaid family labour and increased self-reliance. Goats are multipurpose animals, which provide meat, milk, hair, wool and skin. Among the problems encountered, parasitism is thought to be the major causes of hindering the goat production (Dewan et al., 1979; Nooruddin et al., 1987; Shahiduzzaman et al., 1999). Parasitic infestations are the major veterinary problems in most of the developed \& under developed countries of the world that is responsible for deterioration of the health and productivity of livestock. Haemonchosis is a parasitic disease caused by nematode of Haemonchus $(H$.) spp. The blood sucking parasite H. contortus which is found in the abomasum of the sheep and goat causes significant blood loss; each worm removes $0.05 \mathrm{ml}$ blood per day so that sheep with a $500 \mathrm{H}$. contortus may loss about $250 \mathrm{ml}$ per day (Urquhart et al., 1988). H. contortus is a predominant, highly pathogenic and economically important disease of sheep and goats (Maqsood et al., 1996; Mortensen et al., 2003).

*Corresponding e-mail address: mt.islam@ @ust.edu.bd

Copyright () 2015 Bangladesh Society for Veterinary Medicine

All rights reserved 0323/2015 


\section{Nahar and others}

Bangladesh has a tropical monsoon climate characterized by wide seasonal variations in rainfall, high temperatures, and humidity. Regional climatic differences in this flat country are minor. Three seasons are generally recognized: a hot, muggy summer from March to June; a hot, humid and rainy monsoon season from June to November; and a cold, dry winter from December to February. In general, maximum summer temperatures range between 38 and $41^{\circ} \mathrm{C}\left(100.4\right.$ and $\left.105.8^{\circ} \mathrm{F}\right)$. April is the hottest month in most parts of the country. January is the coolest month, when the average temperature for most of the country is $16-20^{\circ} \mathrm{C}(61$ $\left.68^{\circ} \mathrm{F}\right)$ during the day and around $10^{\circ} \mathrm{C}\left(50^{\circ} \mathrm{F}\right)$ at night. Heavy rainfall is characteristic of Bangladesh causing it to flood every year. With the exception of the relatively dry western region of Rajshahi, where the annual rainfall is about 1,600 mm (63.0 in.), most parts of the country receive at least 2,300 $\mathrm{mm}$ (90.6 in) of rainfall per year. Bangladesh forms the largest delta in the world and is situated between $88^{\circ} 10 \odot$ and $92^{\circ} 41 \odot$ East longitudes and between $20^{\circ} 34(\odot)$ and $26^{\circ} 38(\odot)$ North longitudes. The Rajshahi division is relatively high and cannot hold waters during monsoon (Wikipedia, 2014).

The prevalence of parasitic infestation depends on ecology, geographical and agro-climatic condition prevailing in Bangladesh (Hossain et al., 2004). The geo-climatic conditions of Bangladesh are highly favorable for the growth and multiplication of parasites. The optimal condition for development from egg to L3 is $28{ }^{\circ} \mathrm{C}$ with humidity greater than $70 \%$ (Rossanigo \& Gruner, 1995), and little or no development of eggs to larvae will take place below $9{ }^{\circ} \mathrm{C}$ (Silverman \& Campbell, 1959). On this basis, the environmental conditions in which external larval stages of $H$. contortus can develop and complete their life cycle are limited in cold temperate climates. H. contortus is most prevalent in tropical and subtropical, warm, moist regions of the world (Dorny et al., 1996). Prevalence haemonchosis of goats was frequently observed by other researcher in Mymensingh, Bangladesh (Qadir, 1967, Shahiduzzaman et al., 2003). But there is no report on northern area especially in Rajshahi. Keeping in view, the importance of haemonchosis, the present research was undertaken to determine the effects of mean temperature, relative humidity and total rainfall on monthly occurrence of $H$. spp. infection in Rajshahi, Bangladesh.

\section{MATERIALS AND METHODS Study design}

The present study was designed to assess the month-wise prevalence of haemonchosis of goats in the district of Rajshahi, Bangladesh and was conducted at Laboratory of Animal Husbandry and Veterinary Science, University of Rajshahi during the period starting from March 2011 to February 2012. In this cross-sectional study, a total 720 goats were selected from the villages, farms, pastures, veterinary hospitals and abattoirs by using simple random sampling method and examined for Haemonchus spp. infection.

\section{Examination of sample}

Faecal samples were collected by a two-finger procedure from the rectum of goats and were collected in $4 \%$ formalin in suitable airtight containers, such as screw-cap bottles and plastic bags with unique labels. At necropsy, abomasa were collected after slaughtering and evisceration of the goat in nearby slaughterhouses in the study area. For every sample, the information on month of collection was recorded using a questionnaire. The faecal samples and abomasa were brought into the Laboratory of Animal Husbandry and Veterinary Science, Faculty of Agriculture, University of Rajshahi for the presence of eggs and identification of Haemonchus spp. respectively.

\section{Parasitological technique}

Faecal samples were examined by direct smear and floatation techniques for the presence of Haemonchus spp. eggs (Martin et al., 1990, Samad 2008). Eggs of Haemonchus spp. were identified on the basis of morphology (Soulsby, 1982; Urquhart, 2000). Each abomasum was opened along with the lesser curvature placing on the tray and the contents were placed in a jar containing water. The mucosa was cleaned under running tap water and the washings drained into the bucket, and clean water was added to it to make the desired volume. After thorough stirring, an aliquot of 1:20 was removed from the washings of the abomasum, into a container containing normal saline. The contents and washings of abomasa, were inspected for the presence of mature and immature worms and Haemonchus spp. was identified based on the characteristics reported by Soulsby, (1982) and Zajac et al. (2006). 


\section{Meteorological data}

Meteorological data including temperature (maximum/minimum), relative humidity, total rainfall were obtained from Meteorological station, Shampur, Rajshahi (Table 1).

Table 1. Month-wise maximum, minimum and mean temperature, relative humidity and total rainfall of the study area

\begin{tabular}{llllll}
\hline $\begin{array}{l}\text { Month of collection } \\
\text { of sample during } \\
\text { study period }\end{array}$ & $\begin{array}{l}\text { Maximum } \\
\text { Temperature } \\
\left({ }^{\circ} \mathrm{C}\right)\end{array}$ & $\begin{array}{l}\text { Minimum } \\
\text { Temperature } \\
\left({ }^{\circ} \mathrm{C}\right)\end{array}$ & $\begin{array}{l}\text { Mean } \\
\text { temperature } \\
\left({ }^{\circ} \mathrm{C}\right)\end{array}$ & $\begin{array}{l}\text { Average } \\
\text { relative } \\
\text { humidity } \\
(\%)\end{array}$ & $\begin{array}{l}\text { Total } \\
\text { Rainfall } \\
(\mathrm{mm})\end{array}$ \\
\hline March-2011 & 33.1 & 19.1 & 26.1 & 65 & 11.0 \\
April-2011 & 34.1 & 25.2 & 27.3 & 72 & 93.4 \\
May-2011 & 33.9 & 26.7 & 28.9 & 82 & 187.4 \\
June-2011 & 33.5 & 26.4 & 29.4 & 85 & 341.1 \\
July-2011 & 32.9 & 26.7 & 29.8 & 86 & 146.0 \\
August-2011 & 31.5 & 26.3 & 28.9 & 88 & 454.8 \\
September-2011 & 32.5 & 23.5 & 29.3 & 87 & 202.7 \\
October-2011 & 32.3 & 17.6 & 27.9 & 83 & 34.1 \\
November-2011 & 28.6 & 17.6 & 23.1 & 81 & 1.0 \\
December-2011 & 23.7 & 13.0 & 18.5 & 84 & Nill \\
January-2012 & 22.8 & 11.7 & 17.5 & 79 & 5.5 \\
February-2012 & 27.8 & 12.5 & 20.1 & 66 & 0.6 \\
Overall & 30.6 & 20.6 & 25.6 & 79.8 & 148.1 \\
\hline
\end{tabular}

\section{Statistical analysis}

All the data that were collected entered to MS Excel sheet and analyzed by SPSS version 19. The monthly value was compared using by Duncan Multiple Range Test (DMRT) made by Steel and Torrie (1980). Descriptive statistics was also used to determine the prevalence of haemonchosis and Chi-square test $\left(\chi^{2}\right)$ was used to look the significant difference between months of the year with haemonchosis of goats. The confidence level was held at $95 \%$ and $\mathrm{P}<0.05$ were set for significance.

\section{RESULTS AND DISCUSSION}

The overall prevalence of haemoncahosis was $57.8 \%$, among them $50 \%$ was found positive for identification of eggs of Haemonchus spp. and $65.5 \%$ for the identification of adult and immature worms of $H$. spp. (Table 2). The prevalence of haemonchosis of goats were studied for the evaluation of meteorological factors (temperature, relative humidity and total rainfall) responsible for the occurrence of this disease in the study area. The monthwise prevalence of haemonchosis in goats in relation to meteorological data are presented in Table $4 \&$ Fig. 1 . The haemonchosis was highest in the month of July $(82.1 \%)$ and lowest in January (28.3\%). The average maximum temperature reached $33.9^{\circ} \mathrm{C}$ in May, 2011 and minimum $11.7^{\circ} \mathrm{C}$ in January, 2012. The relative humidity was highest $(88 \%)$ in the month of August and lowest $(65 \%)$ in the month of March (Table 1). In the month of June and September the prevalence were $61.9 \%$ and $71.9 \%$ respectively (Table $4 \&$ figure 1 ). Shahiduzzaman et al. (2003) reported highest prevalence in the month of July (84.42\%) followed by June $(72.58 \%)$ and October $(72.41 \%)$. Whereas, the lowest prevalence of haemonchosis was found $46.15 \%$ in the month of January. The prevalence of infection relates to the humidity during the study period, which also followed an increasing pattern from April to August (72\% to 88\%) and then gradually decreased from September to March (87\% to 65\%). The findings of the study are also in coherent with the findings of Enyenihi et al. (1975) who reported that optimal conditions (hot and humid climate) are really helpful in the development of parasites. This variations in the findings with the earlier report might be due to the differences in sample size, species variation and also in the difference in the climatic condition of the study area. 


\section{Nahar and others}

Table 2. The prevalence of haemonchosis in goats

\begin{tabular}{llllll}
\hline $\begin{array}{l}\text { Type of } \\
\text { examination } \\
\text { procedure }\end{array}$ & $\begin{array}{l}\text { Type of goat } \\
\text { examined }\end{array}$ & $\begin{array}{l}\text { Type of } \\
\text { sample } \\
\text { examined }\end{array}$ & $\begin{array}{l}\text { No of sample } \\
\text { Examined }(\mathrm{n}=)\end{array}$ & $\begin{array}{l}\text { No of Haemonchus } \\
\text { infected sample } \\
(\mathrm{n}=)\end{array}$ & $\begin{array}{l}\text { \% of } \\
\text { haemonchosis }\end{array}$ \\
\hline Coproscopy & Live & Faeces & 363 & 182 & 50.1 \\
$\begin{array}{l}\text { Necropsy } \\
\text { Total }\end{array}$ & Slaughtered & Abomasum & 357 & 234 & 65.5 \\
\hline
\end{tabular}

The hatching of eggs and survival of the infective stage of larvae depends on two most important components of the external environment, which is the temperature and relative humidity. The optimum temperature for the development of maximum number of larvae is the range of $18^{\circ} \dot{\mathrm{C}}-26^{\circ} \dot{\mathrm{C}}$ and humidity is high $100 \%$ although some development can occur down to $80 \%$ however, even in dry weather where the ambient humidity is low, the microclimate in faeces or at the soil surface may be sufficiently humid to permit continual larval development (Taylor et al., 2007). For these reasons, the prevalence was started to decline from November (55.0\% to April $(49.1 \%)$ then increased gradually from May $(61.3 \%)$ to August $(82.1 \%)$. The effect of climatic factors on worm burden revealed a significant positive correlation with rainfall and relative humidity, which favourably support the larvae survival and development. This finding is in consistent with Amenu, (2005) who reported that the higher prevalence and worm burden occur during months of rainy season.

Table 3. Month-wise prevalence of haemonchosis in goats

\begin{tabular}{|c|c|c|c|c|c|}
\hline Month of study & $\begin{array}{l}\text { Total no. of sample } \\
\text { examined (n) }\end{array}$ & $\begin{array}{l}\text { Total no. of Positive } \\
\text { sample (n) }\end{array}$ & $\begin{array}{l}\text { Prevalence } \\
(\%)\end{array}$ & $\begin{array}{l}\text { Chi-square } \\
\text { value }\end{array}$ & $\begin{array}{l}\text { Significance } \\
\text { level }\end{array}$ \\
\hline March-2011 & 52 & 26 & 50.0 & \multirow{13}{*}{79.707} & \multirow{13}{*}{$\begin{array}{l}(.000) \\
* * *\end{array}$} \\
\hline April-2011 & 57 & 28 & 49.1 & & \\
\hline May-2011 & 62 & 38 & 61.3 & & \\
\hline June-2011 & 56 & 46 & 61.9 & & \\
\hline July-2011 & 61 & 45 & 82.1 & & \\
\hline August-2011 & 64 & 51 & 79.7 & & \\
\hline September-2011 & 64 & 46 & 71.9 & & \\
\hline October-2011 & 63 & 39 & 73.3 & & \\
\hline November-2011 & 59 & 32 & 55.0 & & \\
\hline December-2011 & 60 & 24 & 40.0 & & \\
\hline January-2012 & 60 & 17 & 38.7 & & \\
\hline February-2012 & 62 & 24 & 28.3 & & \\
\hline Total & 720 & 416 & 57.8 & & \\
\hline
\end{tabular}

$\mathrm{n}=$ Number of observation, $* * *$ Significant at $0.1 \%$ level $(\mathrm{P}<0.001)$

It was observed that highest prevalence of haemonohosis was recorded during the month of July (82.1\%) and the lowest $(28.3 \%)$ prevalence was recorded during the month of January. This is in agreement with studies 
conducted in different parts of the world (Maingi et al., 1993; Vlasoff et al., 2001; Waruiru et al., 2001; Nginyi et al., 2001; Katoch, 2000; Laha et al., 2001; Khajuria and Kapoor, 2003; Shahadat et al., 2003; Lateef et al., 2005; Keyyu et al., 2005). The prevalence of haemonchosis started to decrease steadily from November to January and increase steadily from January to March. Nwosu et al. (2007) reported that Haemonchus was the most common nematode recorded during their study. They also reported that Haemonchus eggs and adults were high in prevalence and seasonal fluctuation was common in the study area. They further reported the high prevalence during hot humid season. Hansen and Perry (1994) and Urquhart et al. (1996) reported significantly higher parasitic load in the wet season than the dry season.

Self-cure phenomenon is the important for the epidemiology of haemonchosis. In this phenomenon, expulsion of adult parasite from the host takes place simultaeneously although not invariably, eliminate incoming larvae. This may be associated with changes in the pastures, when a large uptake of infective larvae is superimposed on an established worm burden in a sensitized animal. Predisposing factor for haemonchosis include overcrowding, lush pasture, hot and humid weather and a low plane of nutrition. Self cure phenomenon is induced by the acquisition of large number of infective larvae developed in the pasture after heavy rainfall (Soulsby, 1982, Urquhart et al., 1996). It was observed that, during the study period when the rain starts from the month of May, in that month goats were grazed and fed more amount of infective larvae and then infection was occurred. In this context, the highest rate of haemonchosis in the month of July followed by August and June. Re-establishment of infection after self-cure phenomenon is indicated by the gradual increase of prevalence of haemonchosis. This self-cure phenomenon may also be true for haemonchosis of goats in Rajshahi, Bangladesh where the rain starts from the May and creates the conducive environment for the development for the large number of infective larvae in the June and July on the rapidly growing pasture and the goats are easily infected with enormous amount of infective larvae. This is in line with the aggeement of Shahiduzzaman et al. (2003) in Mymensingh, Bangladesh.

Table 4. Month-wise prevalence of haemonchosis in relation to mean temperature, relative humidity and total rainfall of study period

\begin{tabular}{lllll}
\hline $\begin{array}{l}\text { Month of Collection of sample during } \\
\text { study period }\end{array}$ & $\begin{array}{l}\text { Mean temperature } \\
\left({ }^{\circ} \mathrm{C}\right)\end{array}$ & $\begin{array}{l}\text { Relative } \\
\text { humidity } \\
(\%)\end{array}$ & $\begin{array}{l}\text { Total } \\
\text { Rainfall } \\
(\mathrm{mm})\end{array}$ & $\begin{array}{l}\text { Percent of } \\
\text { Infection } \\
(\%)\end{array}$ \\
\hline March-2011 & 26.1 & 65 & 11.0 & $50.0^{\mathrm{de}}$ \\
April-2011 & 27.3 & 72 & 93.4 & $49.1^{\mathrm{e}}$ \\
May-2011 & 28.9 & 82 & 187.4 & $61.3^{\text {cd }}$ \\
June-2011 & 29.4 & 85 & 341.1 & $61.9^{\text {bcd }}$ \\
July-2011 & 29.8 & 86 & 146.0 & $82.1^{\text {a }}$ \\
August-2011 & 28.9 & 88 & 454.8 & $79.7^{\text {ab }}$ \\
September-2011 & 29.3 & 87 & 202.7 & $71.9^{\text {abc }}$ \\
October-2011 & 27.9 & 83 & 34.1 & $73.3^{\text {abc }}$ \\
November-2011 & 23.1 & 81 & 1.0 & $55.0^{\text {cde }}$ \\
December-2011 & 18.5 & 84 & Nill & $40.0^{\text {ef }}$ \\
January-2012 & 17.5 & 79 & 5.5 & $28.3^{\mathrm{f}}$ \\
February-2012 & 20.1 & 66 & 0.6 & $38.7^{\text {ef }}$ \\
\hline Overall & 25.6 & 79.8 & 148.1 & 57.8 \\
\hline
\end{tabular}

Nill=absent, abcdef with different superscript letter in the same column differ significantly with each other $(\mathrm{P}<0.001)$ by DMRT.

In the month of January, the lowest prevalence indicates to the less survival of eggs and pre-infective larvae $\left(\mathrm{L}_{1}, \mathrm{~L}_{2}\right)$ on pasture due to minimum temperature $\left(11.7{ }^{\circ} \mathrm{C}\right)$ less moisture (relative humidity, $\left.79 \%\right)$ and dry condition. Shahiduzzaman et al. (2003) also reported that the lowest percentages of infection in the winter months indicates the less survival of eggs and pre-infective larvae and subsequent development of infective $\mathrm{L}_{3}$ in the pasture as less moisture and dry condition of the pasture as a result goats did not get more infective stages. In the winter months, arrested or inhibited $\left(\mathrm{L}_{4}\right)$ larval development of $H$. spp. occurs due to the adverse environmental conditions, which is known as hypobiosis. In this period, infective larvae did not develop due to low temperature $\left(17.5^{\circ} \mathrm{C}\right)$, humidity $(79 \%)$ and rainfall $(5.5 \mathrm{~mm})$. Arrested larval development plays important 


\section{Nahar and others}

role in the prevalence of the $H$. contortus infection in Rajshahi, Bangladesh. Shahiduzzaman et al. (2003) also stated that hypobiotic phenomenon of larval development of Haemonchus spp. in the host body because of adverse environmental condition influences in the winter as it happens in the temperate countries may also play an important role in Bangladesh. The prevalence of infection started to decline from November to January and then increased gradually from February to May this is similar to the findings of previous report of Al-Dulaimi $e t$ al. (1985). The mean monthly maximum temperature of $18^{\circ} \mathrm{C}$ or above and total monthly rainfall of $50 \mathrm{~mm}$ are conducive for translation and transmission of $H$. contortus (Gordon, 1953; Waller and Chandrawathani, 2005). The overall mean temperature, mean relative humidity and mean rainfall observed in this study were $25.6^{\circ} \mathrm{C}$, $79.8 \%$ and $148.1 \mathrm{~mm}$ respectively which was favourable for the development of Haemonchus larvae and for that haemonchosis was prevalent throughout the year. The findings of this study may help to determine the time of routine deworming in goats against haemonchosis.

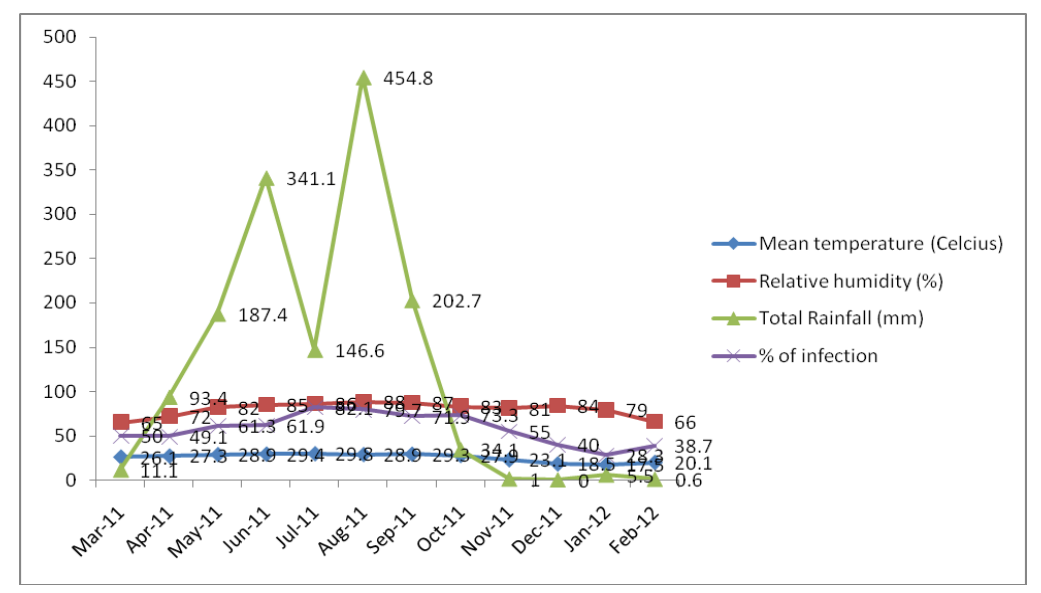

Fig. 1.Graphical representation of the month-wise prevalence of haemonchosis in relation to mean temperature, relative humidity and total rainfall of study period.

In the current study, the highest percentage of haemonchosis was recorded during the month of June followed by August which might be due to the optimum conditions (hot and humid climate) leading to the development and marked increase in the infective stage (L3) in the pasture. In the context of above discussion, it is concluded that goats should be regularly dewormed at the start rainy season and at least once again in December to control such a highly endemic parasitic disease .

\section{ACKNOWLEDGEMENTS}

Authors are thankful to the teachers and staff of the Department of Animal Husbandry and Veterinary Science, Faculty of Agriculture, University of Rajshahi, Bangladesh for their kind cooperation for completing her research. The authors would like to thank to the farmers, butcher's, staff of the veterinary hospital and farms of different Upazilla for providing samples and other facilities. The author also expresses her thanks to the Director of the Meteorological Station, Shampur, Rajshahi for providing meteorological data. The author is highly grateful to the Ministry of Science and Technology for giving financial support.

\section{REFERENCES}

1. Al-Dulaimi FA, Saad MZ, Omar AR and Sheik A (1985). The epidemiology of helminthes in small ruminants. Pertanika 8: 217-230.

2. Amenu A (2005). Epidemiology of gastrointestinal tract nematodiosis of small ruminant in three different agroecological zones of southern Ethiopia. M. Sc., Thesis FVM, AAU, Debre Zeit, Ethiopia.

3. BER (Bangladesh Economic Review), Bangla (2014). http: //www.mof.gov. bd/en/budget/14-15/ber/bn/chapter-7b. 
4. Dewan ML, Hossain MI and Baki MA (1979). Pathological investigation on the mortality of buffalo calves of Bangladesh. Bangladesh Veterinary Journal 13: 1-7.

5. Dorny P, Batabura A, Iskander M and Pandey VS (1996). Helminth infections of sheep in North Sumatra, Indonesia. Veterinary Parasitology 61: 353-358.

6. Enyenihi UK, Okon and and Fabiyi JP (1975). Tapeworms infection of small ruminants in Nigeria. Bulletin of Health Production 23: 289-295.

7. Gordon HM (1953). The epidemiology of helminthosis in sheep in winter-rainfall regions of Australia. I. Preliminary observations. Australian Veterinary Journal 29: 237-248.

8. Hansen J and Perry B (1994). The Epidemiology, Diagnosis and Control of Helminth Parasites of Ruminants. $2^{\text {nd }}$ edition. Nairobi, Kenya; ILRAD.

9. Hossain MJ, Amin M, Mostofa M, Sharif M and Khalid SMA (2004). Efficacy of levanid against natural gastrointestinal nematodiasis and paramphistomiasis in sheep. Bangladesh Veteterinarian 21: 70-73.

10. Katoch R Chauhan PPS and Johri DK (2000). Seasonal incidence of gastrointestinal nematodes in goats of Mathura region. Indian Veterinary Journal 77: 259-260.

11. Keyyu JD, Kyvsgaard NC, Monrad J and Kassuku AA (2005). Epidemiology of gastrointestinal nematodes in cattle on traditional, small-scale dairy and large-scale dairy farms in I district, Tanzania. Veterinary Parasitology 127: 285-294.

12. Khajuria JK and PR Kapoor (2003). Prevalence of parasites in sheep and goats at Kathua-Jammu. Journal of Veterinary Parasitology 17: 121-126.

13. Laha R, Ramakrishna C, Bhattcharya D and Sikdar A (2001). Seasonal incidence of Haemonchus contortus infections in goats-a post mortem study. Indian Journal of Animal Science 71: 345-346.

14. Lateef M, Iqbal Z, Jabbar A, Khan MN and Akhtar MS (2005). Epidemiology of trichostrongylid nematode infections in sheep under traditional husbandry system in Pakistan. .International Journal of Agriculture and Biology 7: 596-600.

15. Maingi N, Gichanga EJ and Gichohi VM (1993). Prevalence of gastrointestinal helminthes and coccidian parasites and frequency distribution of some nematode genera of goats on some farms in four districts of Kenya. Bulletine of Animal Health Production Africa 41: 285-290.

16. Maqsood M, Iqbal Z and Chaudhary AH (1996). Prevalence and intensity of Haemonchosis with reference to breed, sex and age of sheep and goats. Pakistan Veterinary Journal 16: 41-43.

17. Martin RR, Beveridge I, Pullman AL and Brown TH (1990). A modified technique for the estimation of the number of infective larvae present on pasture, and its application in the field under South Australian conditions. Veterinary Parasitology 37: 133-143.

18. Maryah UM (2005). Forage availability and livestock management systems in the neither semi-arid zone of northen Nigeria. Ph.D. Thesis, Bayero University, Nigeria.

19. Mortensen LL, Williamson LH, Terrill TH, Kircher R, Larsen M and Kaplan RM (2003). Evaluation of prevalence and clinical implications of anthelmintic resistance in gastrointestinal nematodes of goats. Journal of Animal Veterinary and Medical Association 23: 495-500.

20. Nginyi JM, Duncan JL, Mellor DJ and Stear MJ (2001). Epidemiology of parasitic gastrointestinal nematode infections of ruminants on small holder farms in central Kenya. Research Veterinary Science 70: 33-39.

21. Nooruddin M, Baki A and Das JG (1987). Clinico-pathological studies of an ichoutbreak of Tr in cow calves. Indian Journal Veterinary Medicine 7: 116-119.

22. Nwosu CO, Madu PP and Richards WS (2007). Prevalence and seasonal changes in the population of gastrointestinal nematodes of small ruminants in the semi- arid zone of north-eastern Nigeria. Veterinary Parasitology 144: 118-124.

23. O'Connor LJ, Walkden-Brown SW and Kahn LP (2006). Ecology of the free-living stages of major trichostrongylid parasites of sheep. Veterinary Parasitology 142: 1-15.

24. Pal RA and Qayyum M (1993). Prevalence of gastrointestinal nematodes of sheep and goats in upper Punjab, Pakistan. Pakistan Veterinary Journal 13: 138-141.

25. Qadir ANMA (1967). Investigation on the incidence of gastro-intestinal parasites of goats in East Pakistan Agricultural University Campus. Indian Veterinary Journal.

26. Rossanigo CE and Gruner L (1995). Moisture and temperature requirements in faeces for the development of freeliving stages of gastrointestinal nematodes of sheep, cattle and deer. Journal of Helminthology 69: 357-362.

27. Samad MA (2008). Animal Husbandry and Veterinary Science 1: 593-594.

28. Shahadat MA, Karim MJ, Alam MZ and umder S (2003). Seasonal distribution of Hain Bengal goats. Bangladesh Veterinary Journal 20: 72-76. 


\section{Nahar and others}

29. Shahiduzzaman M, Talukder MH and Rahman MH (1999). Ecology of preparasitic stages of ruminants in Bangladesh. Bangladesh Veterinary Journal 33: 93-97.

30. Silverman PH and Campbell JA (1959). Studies on parasitic worms of sheep in Scotland. I. Embryonic and larval development of Haemonchus contortus at constant conditions. Parasitology 49: 23-38.

31. Soulsby EJL (1982). Helminths Arthropods and Protozoa of Domesticated Animals. $7^{\text {th }}$ edition, BailliereTindall, London, United Kingdom.

32. Steel RGD and Torrie JH (1980). Principles and procedure statistics. $2^{\text {nd }}$ Ed. McGraw Hill Books Co., New York, 137-171.

33. Taylor MA, Coop RL and Wall RL (2007). Veterinary parasitology. Blackwell Publishing, $3^{\text {rd }}$ edition.

34. Urquhart GM Armour J Duncan JL Dunn AM and Jennings FW (2000). Veterinary Parasitology. $2^{\text {nd }}$ Edition. Blackwell Science Ltd. London.

35. Urquhart GM Armour J Duncan JL Dunn AM and Jennings FW (1996). Veterinary Parasitology. $2^{\text {nd }}$ Edition. Blackwell Science Ltd. London.

36. Urquhart GM Armour J Duncan JL Dunn AM and Jennings FW (1988). Veterinary Parasitology. $2^{\text {nd }}$ Edition. Blackwell Science Ltd. London.

37. Vlasoff A, Leathwick DM and Heath ACG (2001). The epidemiology of nematode infections of sheep. New Zealand Veterinary Journal 49: 213-221.

38. Waller PJ and Chandrawathani P (2005). Haemonchus contortus: Parasite problem No. 1 from Tropics - Polar Circle. Problems and prospects for control based on epidemiology. Tropical Biomedicine 22: 131-137.

39. Waruiru RM, Thamsborg SM, Nansen P, Kyvsgard NC, Bogh HO, Munyua WK. and GJM (2001). The epidemiology of gastrointestinal nematodes of dairy cattle in central Kenya. Tropical Animal Health Production 33: 173-187.

40. Wikipedia (2014). Geography of Bangladesh, http: //en.wikipedia.org./wiki/ Geography of Bangladesh.

41. Zajac MA and Garya C (2006). Veterinary Clinical Parasitology. $7^{\text {th }}$ ed. Black Well Publishing Company, United Kingdom. 